\title{
Helminths of Steindachnerina insculpta in two distinct stretches of the Taquari River, state of Sáo Paulo, Brazil
}

\author{
Helmintos de Steindachnerina insculpta em dois trechos distintos do rio Taquari, Estado de São Paulo, Brasil
}

Aline Angelina Acosta ${ }^{1 *}$; Jamile Queiroz ${ }^{2}$; Heleno Brandāo ${ }^{1}$; Edmir Daniel Carvalho ${ }^{2}$; Reinaldo Jose da Silva ${ }^{1}$

${ }^{1}$ Departamento de Parasitologia, Instituto de Biociências, Univ Estadual Paulista - UNESP, Botucatu, SP, Brasil

${ }^{2}$ Departamento de Morfologia, Instituto de Biociências, Univ Estadual Paulista - UNESP, Botucatu, SP, Brasil

Received June 5, 2013

Accepted November 5, 2013

\begin{abstract}
The purpose of this study was to evaluate the helminth fauna of Steindachnerina insculpta in the Taquari River, a tributary of the Jurumirim reservoir in the state of São Paulo, and to investigate whether some helminth species may act as a bioindicator of environmental impact. The host fish sample was composed of 60 specimens, with 30 individuals sampled in a lotic stretch and 30 in a lentic stretch. The following were found: the monogeneans Anacanthoroides mizelli, Diaphorocleidus kabatai, Urocleidoides sp. and Euryhaliotrema chaoi; the digenean Sphincterodiplostomum musculosum and unidentified metacercariae; the nematode Travnema travnema and unidentified larvae; and the acanthocephalan Gorytocephalus plecostomorum. The total prevalence of monogeneans $(\mathrm{z}=3.14 ; \mathrm{p}=0.002)$ and A. mizelli $(\mathrm{z}=3.879$; $\mathrm{p} \leq 0.001)$, as well as the mean abundance of total monogeneans $(\mathrm{U}=642.0 ; \mathrm{p} \leq 0.001)$ and A. mizelli $(\mathrm{U}=623.5$; $\mathrm{p} \leq 0.001$ ), were higher in the lentic stretch. Steindachnerina insculpta and its monogeneans comprise a potential group that could be used to investigate environmental impact, as demonstrated in this study.
\end{abstract}

Keywords: Neotropical fish, teleost, parasites, bioindicator, reservoir.

\section{Resumo}

O objetivo desde estudo foi avaliar a helmintofauna de Steindachnerina insculpta no rio Taquari, um tributário do reservatório de Jurumirim, estado de São Paulo, e verificar se alguma espécie pode agir como bioindicadora de impacto ambiental. A amostragem de peixes foi composta de 60 espécimes, com 30 indivíduos amostrados no trecho lótico e 30 no trecho lêntico. Foram encontrados os monogenóides: Anacanthoroides mizelli, Diaphorocleidus kabatai, Urocleidoides sp. e Euryhaliotrema chaoi; o digenético Sphincterodiplostomum musculosum e metacercárias não identificadas, o nematoide Travnema travnema e larvas não identificadas; e o acantocéfalo Gorytocephalus plecostomorum. A prevalência total de monogenóides $(\mathrm{z}=3,14 ; \mathrm{p}=0,002)$ e A. mizelli $(\mathrm{z}=3,879 ; \mathrm{p} \leq 0,001)$ e também a abundância média de monogenóides total $(\mathrm{U}=642,0 ; \mathrm{p} \leq 0,001)$ e A. mizelli $(\mathrm{U}=623,5 ; \mathrm{p} \leq 0,001)$ foram maiores no trecho lêntico. Steindachnerina insculpta e seus monogenóides compóem um grupo em potencial que pode ser usado para investigar impactos ambientais, como mostrado neste estudo.

Palavras-chave: Peixes Neotropicais, teleósteos, parasitas, bioindicador, reservatório.

\section{Introduction}

Steindachnerina insculpta, popularly known as "saguiru", belongs to the Curimatidae family and has wide geographical distribution in South America (REIS et al., 2003). It is especially abundant in the Paranapanema River and is well-adjusted to artificial reservoirs. The main characteristics of this species are: body slightly silver, terminal mouth without teeth, sedentary with external fertilization, no parental care, and iliophagous feeding habit (DUKE ENERGY, 2008; BRANDÃO et al., 2009).

\footnotetext{
${ }^{*}$ Corresponding author: Aline Angelina Acosta

Departamento de Parasitologia, Instituto de Biociências, Universidade Estadual Paulista - UNESP, Distrito de Rubiáo Júnior, s/n, CEP 18618-970, Botucatu, SP, Brasil

e-mail: alineacosta1@gmail.com
}

The construction of dams is one of the most damaging activities in the Parana river-basin, affecting the main course of the river (AGOSTINHO et al., 2008). Fish assemblages suffer drastically due to the impact of reservoirs, which leads to predominance of generalist fish species (FREEMAN et al., 2001), depletion of migratory species (BRITTO; CARVALHO, 2006) and transference of pathogens and parasites (GABRIELLI; ORSI, 2000). Considering the impact of reservoirs on fish abundance, the prevalence and size of fish parasite infracommunities may also be influenced (PAVANELLI; TAKEMOTO, 2000). The Taquari River is the second biggest tributary of the Jurumirim reservoir (HENRY; NOGUEIRA, 1999) and is one of the main tributaries of the Paranapanema River, which has been significantly affected 
by the creation of the reservoir. There is strong local interest in artisanal fishing in the Taquari River because of the great diversity and abundance of fish. To date, there is no record of parasitological studies in this river.

Fish parasites are considered to be bioindicator species since they can reflect environmental impacts through their response to habitat alterations, such as changes in physiology, chemical composition and prevalence or intensity (VIDAL-MARTÍNEZ et al., 2010). In this context, monogeneans of fish have been used to assess environmental impacts, since they have been shown to be suitable indicators (MADI; UETA, 2009). Steindachnerina insculpta is a host that fits the criteria proposed by Overstreet (1997) and Sures (2004) to serve as a bioindicator fish species: restricted home range, parasites needing more than one host in the life cycle, easy to sample, small size and wide geographical distribution.

Thus, the aim of this study was to assess the helminth fauna of S. insculpta in the Taquari River, São Paulo, and investigate whether some helminth species in the parasite community are potential bioindicator of environmental impacts.

\section{Materials and Methods}

\section{Study area}

The Jurumirim reservoir constitutes a hydric complex formed by a water body with a surface area of $449 \mathrm{~km}^{2}$ and three main tributaries: Paranapanema, Veados and Taquari rivers. The
Taquari River (Figure 1) is in confluence with the left bank of the Upper Paranapanema River, located in a tropical region in the southeastern portion of the state of Sáo Paulo $\left(23^{\circ} 15^{\prime} 11,9^{\prime \prime} \mathrm{S}\right.$ and $49^{\circ} 12^{\prime} 34,2$ 'W). The fluctuations of the water level are determined either by natural events (rainy and dry seasons) or artificial events (the reservoir operation system).

Steindachnerina insculpta specimens were sampled in two stretches: a lotic site (upper stretch) located upstream (23 40' 2.90" S and $49^{\circ} 7^{\prime} 56.85^{\prime \prime} \mathrm{W}$ ) with riparian forest, swamps and macrophytes; and a lentic site (reservoir stretch) located at the river mouth, flooded by the Jurumirim reservoir and located approximately $10 \mathrm{~km}$ away from the dam (23 $17^{\prime} 2.80^{\prime \prime} \mathrm{S}$ and $\left.49^{\circ} 12^{\prime} 6.90^{\prime \prime} \mathrm{W}\right)$. At the lentic site, there is an absence of riparian forest and macrophytes, and the banks are occupied by pasture lands, agricultural activity, and sand extraction activities. The physicochemical characteristics of the lentic and lotic stretches are presented in Table 1.

\section{Field and laboratory procedures}

The fish were sampled in November and December 2011, using gill nets exposed for approximately 14 hours in two distinct areas: the upper stretch of the Taquari River (lotic site) and the reservoir stretch of the Taquari River (lentic site). The fish sample was composed of 60 specimens, with 30 specimens sampled in the lotic stretch, and 30 in the lentic stretch. After sampling, the fish were placed in individual plastic bags, frozen and taken to the laboratory for parasitological analyses. The standard length in centimeters $\left(\mathrm{L}_{\mathrm{s}}\right)$ and total weight in grams $\left(\mathrm{W}_{\mathrm{t}}\right)$ of the fish were measured using an ichthyometer and a precise scale in centigrams.

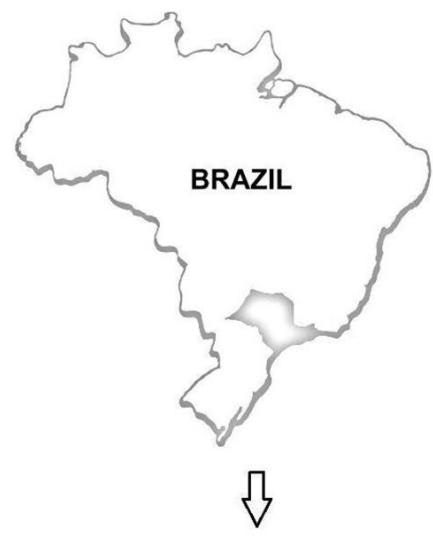

SÃO PAULO STATE

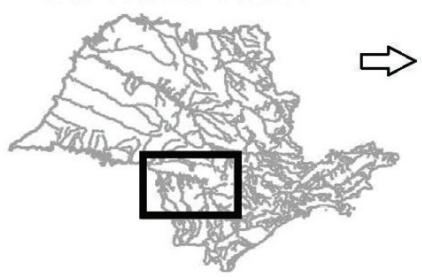

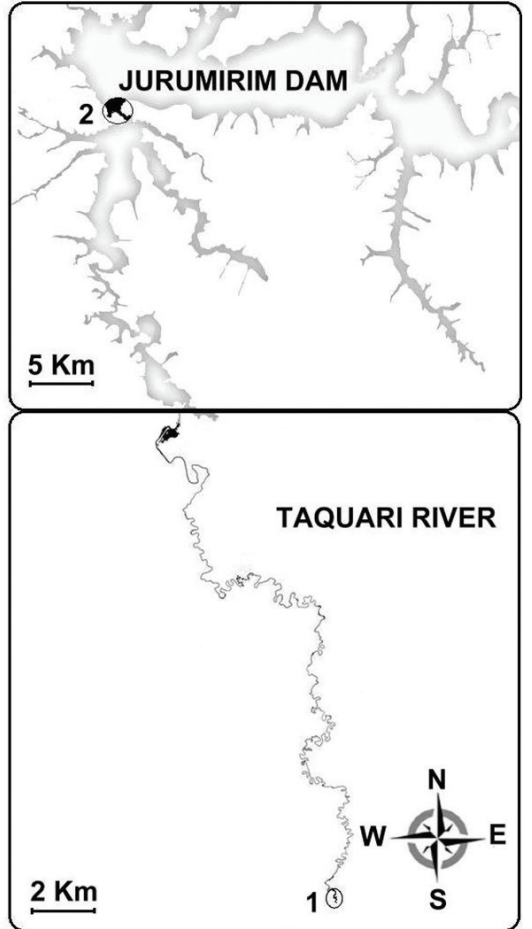

Figure 1. Map of the location of the Taquari River, a tributary of the Jurumirim Reservoir, state of São Paulo, Brazil: 1: upper stretch (lotic); 2: reservoir stretch (lentic). 
Table 1. Mean values and standard deviations of the limnological parameters of the water surface for the two stretches of the Taquari River, Jurumirim reservoir, state of São Paulo, Brazil.

\begin{tabular}{lcc}
\hline \multirow{2}{*}{\multicolumn{1}{c}{ Variables }} & \multicolumn{2}{c}{ Stretches } \\
\cline { 2 - 3 } & Lotic & Lentic \\
\hline Water temperature $\left({ }^{\circ} \mathbf{C}\right)$ & $20.5 \pm 3.88$ & $23.8 \pm 3.85$ \\
pH & $7.0 \pm 0.48$ & $7.1 \pm 0.42$ \\
Conductivity $(\mu \mathrm{S} / \mathbf{c m})$ & $116.8 \pm 24.77$ & $61.8 \pm 7.48$ \\
DO $(\mathbf{m g} / \mathbf{L})$ & $9.7 \pm 33.14$ & $8.7 \pm 28.25$ \\
Water transparency $(\mathbf{m})$ & $0.6 \pm 0.14$ & $3.4 \pm 0.67$ \\
Depth $(\mathbf{m})$ & $2.5 \pm 0.83$ & $61.8 \pm 7.48$ \\
Width between banks $(\mathbf{m})$ & 10 to 20 & 630 to 1400 \\
\hline
\end{tabular}

Fish voucher specimens were deposited in the Fish Biology and Genetics Laboratory, Institute of Biosciences (LBP 13313), Universidade Estadual Paulista (UNESP), municipality of Botucatu, state of São Paulo, Brazil.

\section{Parasitological analyses}

The body, fins, nasal cavity, eyes and inner face of the operculum of the fish hosts were examined to find ectoparasites. The gills were subsequently removed and washed using 53 and 75 micrometer sieves and placed in Petri dishes. The parasites were collected using a stereomicroscope. After the external analyses, a longitudinal incision in the ventral surface was made and all inner organs were removed and separated. The visceral cavity and all organs were examined using a stereomicroscope to locate endoparasites. All helminths collected were preserved in $70 \%$ alcohol. For species identification, the monogeneans were cleared with Hoyer or Grey \& Wess to view the sclerotized structures; the digeneans were stained with carmine and cleared with creosote; and the nematodes were diaphanized with lactophenol (EIRAS et al., 2006).

The parasites were identified based mainly on identification keys and reference guides and were analyzed using the Qwin Lite 3.1 (Leica) computerized system for image analysis. Representatives of the helminth species were deposited in the Helminthological Collection of the Institute of Biosciences (CHIBB), UNESP, municipality of Botucatu, state of São Paulo, Brazil.

\section{Statistical analysis}

The ecological terminology, prevalence, infection/infestation mean intensity, and mean abundance followed Bush et al. (1997). The infracommunity components were classified in accordance with Bush and Holmes (1986) into core species (prevalence higher than $66.6 \%$ ), secondary species (prevalence between $33.3 \%$ and $66.6 \%$ ) and satellite species (prevalence less than 33\%).

To determine the ecological attributes of infracommunities, the Shannon-Wiener diversity index was calculated: $\mathrm{H}^{\prime}=-\sum$ (pi.In pi). This was used to measure the order or disorder in a system, by attributing greater weight to rare species, and was relatively independent of sample size. In the formula, H' = species diversity; $\mathrm{pi}=$ proportion of species $\mathrm{i}$ in the community, in which $\mathrm{pi}=(\mathrm{ni} / \mathrm{N})$; $\mathrm{ni}=$ individual numbers of $\mathrm{i}$ species and $\mathrm{N}=$ total number of individuals (KREBS, 1989; BEGON et al., 2007). Pielou's evenness, which is a derivate from the Shannon-Wiener index, was determined using the following formula: $\left(J^{\prime}=\mathrm{H}^{\prime} / \log _{2} S\right)$, in which J'= evenness (ranging from 0 to 1) (KREBS, 1989).

Similarity analysis on parasites communities between the stretches studied was carried out using the Jaccard coefficient, which is based on the presence or absence of the local species sampled. This index ranged from 0 (dissimilar) to 1 (similar) and was calculated from the equation $(Q=c /(a+b-c) .100)$, in which $Q=$ Jaccard similarity coefficient; $c=$ number of species in common between $\mathrm{a}$ and $\mathrm{b} ; \mathrm{a}=$ number of species sampled in $\mathrm{a}$; and $b=$ number of species sampled in b (KREBS, 1989).

The discrepancy index (D), described by Poulin (1993), was used to evaluate the spatial distribution of parasites based on their abundance between lotic and lentic stretches. This index ranges from 0 to 1 , and can be interpreted as: $\mathrm{D}=0$, all hosts harboring the same number of parasites; $\mathrm{D}=1$, all parasites found in a single host. This analysis was calculated in accordance with Rózsa et al., (2000) using the Quantitative Parasitology 3.0 software.

The prevalence of parasites in the lotic and lentic stretches was compared using Z-test calculations. The mean intensity of infection/ infestation and mean abundance between the two stretches were calculated using the Mann-Whitney U test. Principal component analysis (PCA) was carried out to compare parasite communities in the lotic and lentic stretches.

All values that corresponded to the variable mean were followed by their respective standard error. Statistical comparisons were made using the SigmaStat 3.1 software. The multivariate analysis was calculated using the MVSP software. The statistical significance level used was $P<0.05$.

\section{Results}

\section{Parasite communities}

In the lotic stretch, all hosts analyzed were parasitized by at least one helminth species (total prevalence $=100 \%$ ). A total of 1,527 parasites were collected, with a mean of 50.9 parasite/fish. The richness varied from 1 to 4 parasites, and the mean richness was 2.7 parasites/host. Nine helminth parasite taxa were found: the monogenean species Anacanthoroides mizelli (CHIBB 089L; 090L), Diaphorocleidus kabatai (CHIBB 091L), Urocleidoides sp. (CHIBB 093L; 094L) and Euryhaliotrema chaoi (CHIBB 092L); metacercariae of Sphincterodiplostomum musculosum (CHIBB 7064) and another digenean metacercaria that could not be identified; the nematode species Travnema travnema (CHIBB 7066) and unidentified larvae (CHIBB 7067); and the acanthocephalan Gorytocephalus plecostomorum (CHIBB 7065) (Table 2).

Metacercariae of $S$. musculosum and the acanthocephalan G. plecostomorum were classified as core species. However, only metacercariae of $S$. musculosum showed high abundance and mean intensity of infection. All the other taxa were classified as satellite species, with low rates of abundance and mean intensity of infection/infestation (Table 2). 
In the lentic stretch, all hosts analyzed were parasitized by at least one helminth species (total prevalence $=100 \%$ ). A total of 1,372 parasites were collected, with a mean of 45.7 parasites/fish. The richness varied from 2 to 5 parasites with a mean richness of 3.3 parasites/host. Seven helminth parasite taxa were found: the monogenean species $A$. mizelli and $D$. kabatai; metacercariae of S. musculosum and another digenean metacercaria that could not be identified; nematode species T. travnema and unidentified larvae; and the acanthocephalan $G$. plecostomorum (Table 2).

The monogenean $A$. mizelli, metacercariae of $S$. musculosum and the acanthocephalan $G$. plecostomorum were classified as core species, T. travnema was classified as a secondary species and the other taxa were classified as satellite species. Only the metacercariae of $S$. musculosum showed high rates of abundance and mean intensity of infection (Table 2).

\section{Comparison between lotic and lentic stretches}

The total prevalence $(\mathrm{z}=-1.297 ; \mathrm{p}=0.194)$, total abundance and mean intensity of infection/infestation $(U=956.0 ; p=0.549)$ were similar between the stretches. The mean richness was greater in the lentic stretch $(U=756.0 ; p=0.019)$, but the number of species was greater in the lotic stretch.
The prevalences of total monogenean species $(\mathrm{z}=3.14$; $\mathrm{p}=0.002)$ and $A$. mizelli $(\mathrm{z}=3.879 ; \mathrm{p} \leq 0.001)$ (Figure 2), as well as the mean abundance of total monogenean species $(\mathrm{U}=642.0 ; \mathrm{p}$ $\leq 0.001$ ) and $A$. mizelli ( $\mathrm{U}=623.5 ; \mathrm{p} \leq 0.001)$, were significantly higher in the lentic stretch (Figure 3 ).

The Jaccard index $(S J=8.0)$ showed high similarity among the parasite communities of the two stretches. However, the Shannon-Wiener index showed that the parasite communities in the lentic stretch were greater in diversity than in the lotic stretch. Pielou's evenness indexes were low for both stretches, suggesting the existence of a dominant species (Table 3). The Berger-Park index showed that in both stretches, metacercariae of $S$. musculosum were the dominant species with similar values (Table 4).

It was also observed that most of the parasite species showed aggregated distribution patterns for both stretches. Only species that occurred at high prevalence and mean abundance (metacercariae of S. musculosum and the acanthocephalan G. plecostomorum) showed a medium aggregation index (Table 5).

The multivariate analysis based on component communities of helminth parasites of $S$. insculpta led to the observation that there was relative separation between the specimens from the lotic stretch (mostly distributed in the upper squares) and lentic stretch (mostly distributed in the lower squares). In this analysis, it was observed that A. mizelli, G. plecostomorum and T. travnema

Table 2. Number of parasites $(\mathrm{N})$; prevalence $(\mathrm{P})$; mean intensity of infection/infestation $(\mathrm{MII} \pm \mathrm{SE})$; mean abundance $(\mathrm{MA} \pm \mathrm{SE})$ and infection/infestation sites (IS) of the helminth parasites of Steindachnerina insculpta collected in the lotic and lentic stretches of the Taquari River, Jurumirim reservoir, state of São Paulo, Brazil.

\begin{tabular}{|c|c|c|c|c|c|c|c|c|c|}
\hline \multirow{2}{*}{ Species } & \multicolumn{4}{|c|}{ Lotic } & \multicolumn{4}{|c|}{ Lentic } & \multirow{2}{*}{ IS } \\
\hline & $\mathbf{N}$ & $\mathbf{P}(\%)$ & MII & MA & $\mathbf{N}$ & $\mathbf{P}(\%)$ & MII & MA & \\
\hline Monogeneans & 19 & 36.7 & $\begin{array}{l}1.7 \pm 0.3 \\
(1-5)\end{array}$ & $\begin{array}{c}0.6 \pm 0.2 \\
(0-5)\end{array}$ & 116 & 80 & $\begin{array}{c}4.8 \pm 1.1 \\
(1-27)\end{array}$ & $\begin{array}{l}3.9 \pm 0.9 \\
(0-27)\end{array}$ & $\mathrm{S}, \mathrm{G}, \mathrm{ON}$ \\
\hline Anacanthoroides mizelli & 15 & 26.7 & $\begin{array}{c}1.9 \pm 1.4 \\
(1-5)\end{array}$ & $0.5 \pm 1.1(0-5)$ & 115 & 80 & $\begin{array}{c}4.8 \pm 1.1 \\
(1-27)\end{array}$ & $\begin{array}{l}3.8 \pm 0.9 \\
(0-27)\end{array}$ & $\mathrm{S}, \mathrm{G}, \mathrm{ON}$ \\
\hline Diaphorocleidus kabatai & 1 & 3.3 & 1 & $\begin{array}{l}0.03 \pm 0.03 \\
\quad(0-1)\end{array}$ & 1 & 3,3 & 1 & $\begin{array}{l}0.03 \pm 0.03 \\
\quad(0-1)\end{array}$ & S, G \\
\hline Urocleidoides sp. & 2 & 6.7 & 1 & $\begin{array}{l}0.07 \pm 0.05 \\
\quad(0-1)\end{array}$ & - & - & - & - & G \\
\hline Euryhaliotrema chaoi & 1 & 3.3 & 1 & $\begin{array}{l}0.03 \pm 0.03 \\
\quad(0-1)\end{array}$ & - & - & - & - & G \\
\hline Digeneans & 1397 & 100 & $\begin{array}{l}46.5 \pm 10.2 \\
\quad(1-250)\end{array}$ & $\begin{array}{l}46.5 \pm 10.2 \\
\quad(1-250)\end{array}$ & 1097 & 100 & $\begin{array}{l}36.5 \pm 10.2 \\
(2-286)\end{array}$ & $\begin{array}{l}36.5 \pm 10.2 \\
(2-286)\end{array}$ & E, S, G \\
\hline $\begin{array}{l}\text { Sphincterodiplostomum mus- } \\
\text { culosum (metacercariae) }\end{array}$ & 1394 & 100 & $\begin{array}{l}46.5 \pm 10.2 \\
(1-250)\end{array}$ & $\begin{array}{l}46.5 \pm 10.2 \\
\quad(1-250)\end{array}$ & 1095 & 100 & $\begin{array}{l}36.5 \pm 10.2 \\
(2-286)\end{array}$ & $\begin{array}{l}36.5 \pm 10.2 \\
(2-286)\end{array}$ & $\mathrm{E}$ \\
\hline Unidentified metacercariae & 3 & 6.6 & $\begin{array}{l}1.5 \pm 0.5 \\
(1-2)\end{array}$ & $\begin{array}{l}0.1 \pm 0.07 \\
(0-2)\end{array}$ & 2 & 6,6 & $\begin{array}{c}1.0 \pm 0 \\
(1-2)\end{array}$ & $\begin{array}{l}0.07 \pm 0.07 \\
\quad(0-2)\end{array}$ & S, G \\
\hline Nematodes & 29 & 40 & $\begin{array}{l}2.4 \pm 0.6 \\
(1-8)\end{array}$ & $\begin{array}{c}1 \pm 0.3 \\
(0-8)\end{array}$ & 37 & 47 & $\begin{array}{c}2.6 \pm 0.4 \\
(1-5)\end{array}$ & $\begin{array}{l}1.2 \pm 0.3 \\
(0-5)\end{array}$ & $\mathrm{I}, \mathrm{Ca}$ \\
\hline Travnema travnema & 14 & 24 & $\begin{array}{c}2 \pm 0.4 \\
(1-4)\end{array}$ & $\begin{array}{l}0.5 \pm 0.2 \\
(0-4)\end{array}$ & 22 & 34 & $\begin{array}{l}2.2 \pm 0.4 \\
(1-4)\end{array}$ & $\begin{array}{l}0.7 \pm 0.2 \\
\quad(0-4)\end{array}$ & I \\
\hline Unidentified larvae & 15 & 17 & $\begin{array}{c}3 \pm 1.3 \\
(1-8)\end{array}$ & $\begin{array}{l}0.5 \pm 0.3 \\
(0-8)\end{array}$ & 15 & 30 & $\begin{array}{c}1.7 \pm 0.2 \\
(1-3)\end{array}$ & $\begin{array}{l}0.5 \pm 0.2 \\
(0-3)\end{array}$ & $\mathrm{Ca}$ \\
\hline \multicolumn{10}{|l|}{ Acanthocephalans } \\
\hline Gorytocephalus plecostomorum & 82 & 80 & $\begin{array}{l}3.4 \pm 0.5 \\
(1-10)\end{array}$ & $\begin{array}{l}2.7 \pm 0.5 \\
(0-10)\end{array}$ & 122 & 84 & $\begin{array}{c}4.8 \pm 1.3 \\
(1-32)\end{array}$ & $\begin{array}{l}4.1 \pm 1.2 \\
(0-32)\end{array}$ & I \\
\hline
\end{tabular}

$\mathrm{S}$ - skin; G - gills; NO - nasal operculum; E - eyes; $\mathrm{Ca}$ - cavity; I - intestine. 


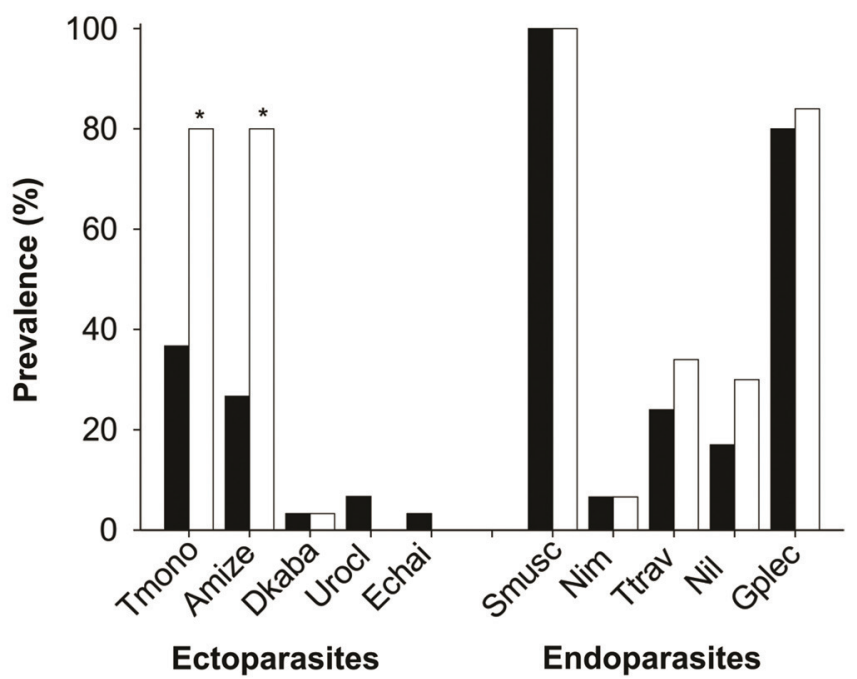

Figure 2. Prevalence of helminth parasites of Steindachnerina insculpta sampled in the lotic and lentic stretches of the Taquari River, Jurumirim reservoir, state of São Paulo, Brazil. Caption: Tmono - total monogeneans; Amize - Anacanthoroides mizelli; Dkaba - Diaphorocleidus kabatai; Urocl - Urocleidoides sp.; Echai - Euryhaliotrema chaoi; Smusc - Sphincterodiplostomum musculosum metacercariae; Nim - unidentified metacercariae; Ttrav - Travnema travnema; Nil - unidentified larvae; Gplec - Gorytocephalus plecostomorum. ${ }^{*} \mathrm{p}<0.05$. Black bars: lotic stretch; White bars: lentic stretch.

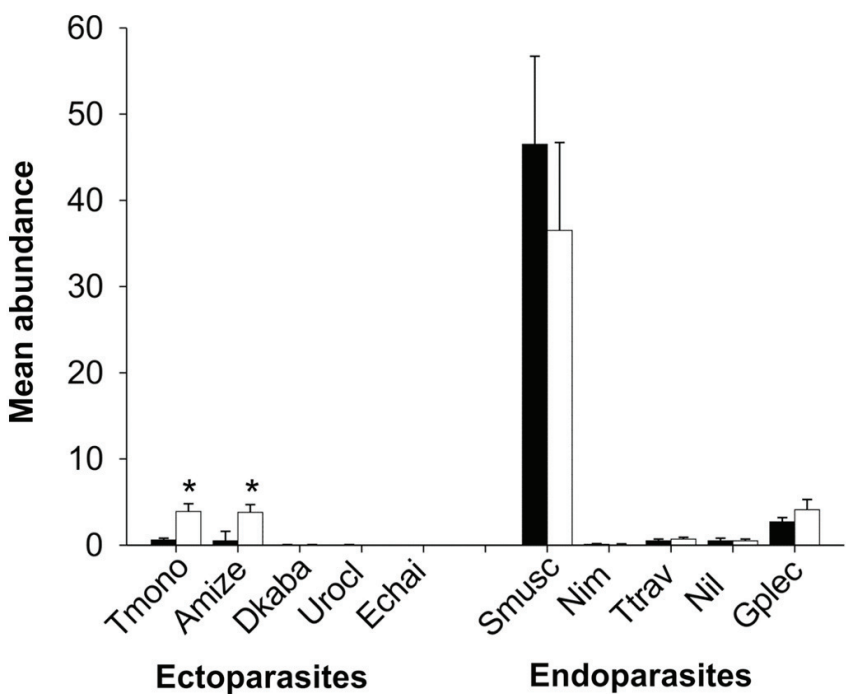

Figure 3. Mean abundance of helminth parasites of Steindachnerina insculpta sampled in the lotic and lentic stretches of the Taquari River, Jurumirim reservoir, state of São Paulo, Brazil. Caption: Tmono - total monogeneans; Amize - Anacanthoroides mizelli; Dkaba - Diaphorocleidus kabatai; Urocl - Urocleidoides sp.; Echai - Euryhaliotrema chaoi; Smusc - Sphincterodiplostomum musculosum metacercariae; Nim - unidentified metacercariae; Trav - Travnema travnema; Nil - unidentified larvae; Gplec - Gorytocephalus plecostomorum. ${ }^{*} \mathrm{p}<0.05$. Black bars: lotic stretch; White bars: lentic stretch.
Table 3. Ecological indexes for the parasite communities of Steindachnerina insculpta sampled in the lotic and lentic stretches of the Taquari River, Jurumirim reservoir, state of São Paulo, Brazil.

\begin{tabular}{lcc}
\hline Ecological indexes & Lotic & Lentic \\
\hline Shannon-Wiener & 0.40 & 0.69 \\
Pielou's evenness & 0.13 & 0.25 \\
\hline
\end{tabular}

were the main species responsible for this separation, in vectorial importance order, respectively (Figure 4).

\section{Discussion}

Considering the analyses of the limnological parameters, it was possible to confirm that the lentic and lotic stretches of the Taquari River are distinct. Downstream flooding areas are more abruptly affected by impoundments and flood pulses, thus altering the natural process. Additionally, variations in the flood pulse may affect floodplains through altering the water levels that define the limits of riparian vegetation (JUNK et al., 1989).

There have been a few recent studies about the helminth parasite fauna of S. insculpta. Takemoto et al. (2009) found the monogenean Urocleidoides sp., metacercariae of Diplostomum sp. (Digenea: Diplostomatidae) and the nematodes T. travnema and Cosmoxynema vianai in S. insculpta samples from the Upper Paraná River floodplain. In a study on new host and distribution records of nematodes in the Peixe River, state of São Paulo, Abdallah et al. (2012) reported occurrences of C. vianai, Guyanema sp., Ichthyouris sp., and T. travnema. Finally, Zago et al. (2013) reported for the first time metacercariae of $S$. musculosum in $S$. insculpta in the Chavantes reservoir, state of São Paulo. Furthermore, Ceschini et al. (2010) studied the endoparasite fauna of the congeneric species Steindachnerina brevipinna sampled in the Paranapanema River, state of Paraná, Brazil, and found metacercariae of $S$. musculosum and the nematode T. travnema.

The helminth parasites found in S. insculpta are generalists and had been already reported in other freshwater fish hosts (Table 6). The monogeneans A. mizelli, D. kabatai and E. chaoi, and the acanthocephalan $G$. plecostomorum found in the present study are new host records for $S$. insculpta. Nevertheless, all the records found represent new geographical distribution for these parasites, given that there were no previous parasitological studies conducted in the Taquari River, São Paulo. One monogenean specimen found was identified only at genus level (Urocleidoides), due to difficulties in viewing the structures, and thus it was not possible to assess host-parasite interactions for it.

Metacercariae of $S$. musculosum were the dominant species in the lotic and lentic stretches, occurring in $100 \%$ of the hosts, and at high abundance. Zago et al. (2013) reported lower prevalence $(96.67 \%)$ for these metacercariae than in the present study. However the mean intensity of infection (96.6 versus 41.5$)$ and mean abundance (93.3 versus 41.5) were higher. Moreover, Zago et al. (2013) found S. musculosum also parasitizing the coelomic cavity. Ceschini et al. (2010) found these metacercariae in S. brevipinna, but they were in the ovary of the hosts, with lower prevalence 
Table 4. Berger-Parker index for the helminth species of Steindachnerina insculpta sampled in the lotic and lentic stretches of the Taquari River, Jurumirim reservoir, state of São Paulo, Brazil.

\begin{tabular}{lcc}
\hline \multicolumn{1}{c}{ Helminth } & Lotic & Lentic \\
\hline Monogeneans & & 0.084 \\
Anacanthoroides mizelli & 0.010 & 0.001 \\
Diaphorocleidus kabatai & 0.001 & - \\
Urocleidoides sp. & 0.001 & - \\
Euryhaliotrema chaoi & 0.001 & \\
Digeneans & & 0.913 \\
Sphincterodiplostomum musculosum (Metacercariae) & 0.002 & 0.001 \\
Unidentified metacercariae & & 0.016 \\
Nematodes & 0.009 & 0.011 \\
Travnema travnema & 0.010 & \\
Unidentified larvae & & 0.061 \\
Acanthocephalans & 0.054 & \\
Gorytocephalus plecostomorum & & \\
\hline
\end{tabular}

Table 5. Aggregation index for the helminth species of Steindachnerina insculpta sampled in the lotic and lentic stretches of the Taquari River, Jurumirim reservoir, state of São Paulo, Brazil.

\begin{tabular}{lcc}
\hline \multicolumn{1}{c}{ Species } & Lotic & Lentic \\
\hline Anacanthoroides mizelli & 0.779 & 0.537 \\
Diaphorocleidus kabatai & 0.935 & 0.935 \\
Urocleidoides sp. & 0.903 & - \\
Euryhaliotrema chaoi & 0.779 & - \\
Sphincterodiplostomum musculosum (Metacercariae) & 0.534 & 0.579 \\
Unidentified metacercariae & 0.914 & 0.935 \\
Travnema travnema & 0.806 & 0.739 \\
Unidentified larvae & 0.875 & 0.738 \\
Gorytocephalus plecostomorum & 0.482 & 0.516 \\
\hline
\end{tabular}

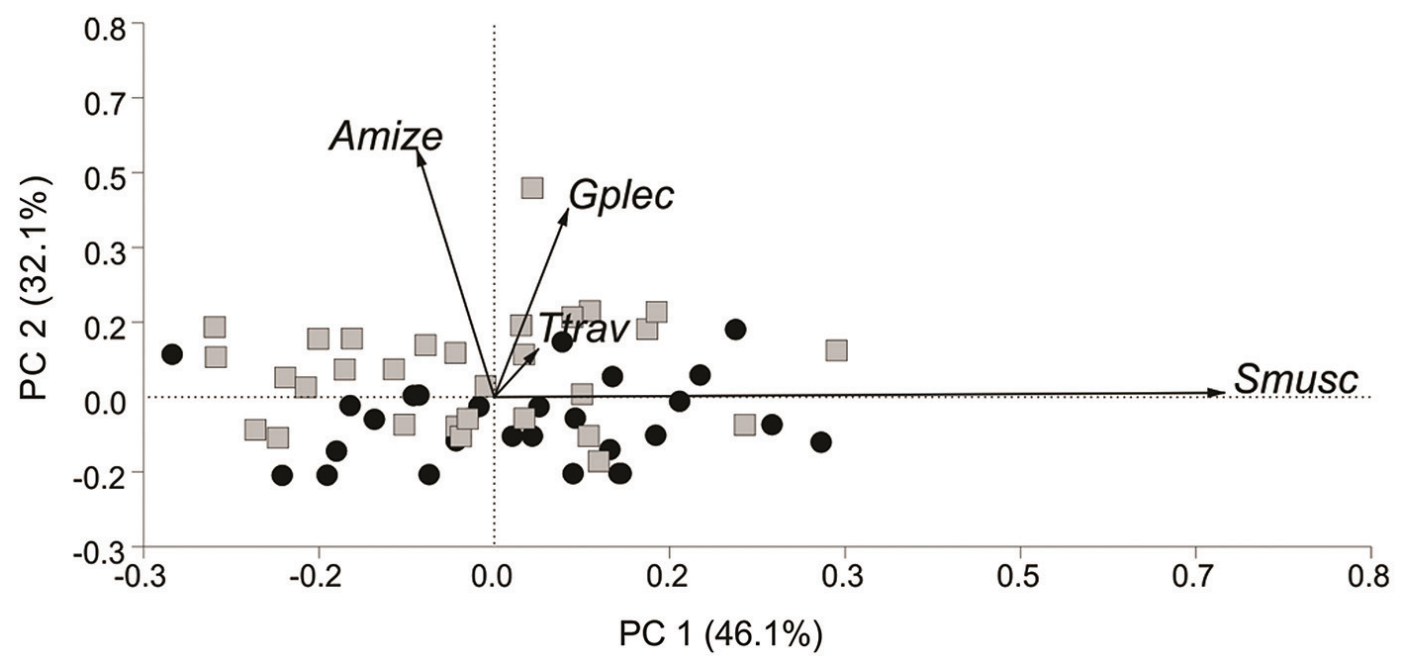

Figure 4. Scatterplot scores of the principal component analysis (PCA) on parasite communities of Steindachnerina insculpta in the lotic stretch $(\bullet)$ and lentic stretches $(\square)$ of the Taquari River, Jurumirim reservoir, state of São Paulo, Brazil. The values shown on the ordinate and abscissa axes represent the greatest quantity and variation of the data set. Vectorial scale $=0.71$. Amize - Anacanthoroides mizelli; Gplec - Gorytocephalus plecostomorum; Smusc - Sphincterodiplostomum musculosum metacercariae; Ttrav - Travnema travnema. 
Table 6. Helminth list of Steindachnerina insculpta and records in other freshwater fish hosts.

\begin{tabular}{lll}
\hline \multicolumn{1}{c}{ Helminth } & \multicolumn{1}{c}{ Host } & \multicolumn{1}{c}{ Reference } \\
\hline Monogeneans & Prochilodus reticulatus & Kritsky and Thatcher (1976) \\
Anacanthoroides mizelli & Astyanax fasciatus & Mendonza-Franco et al. (2009) \\
Diapharocleidus kabatai & Astyanax altiparanae & Almeida and Cohen (2011) \\
& Plagioscion squamosissimus & Kritsky and Boeger (2002) \\
Euryhaliotrema chaoi & & \\
Digeneans & Steindachnerina brevipinna & Ceschini et al. (2010) \\
Sphincterodiplostomum musculosum (metacercaria) & Hoplias malabaricus & Takemoto et al. (2009) \\
& Cyphocharax gilbert & Abdallah et al. (2005) \\
Nematodes & & \\
Travnema travnema & Astyanax bimaculatus & Abdallah et al. (2004) \\
& Curimata elegans & Pereira (1938) \\
& Cyphocarax gilberti & Luque et al. (2011) \\
& Pseudocurimata plumbea & Luque et al. (2011) \\
& Steindachnerina brevipinna & Ceschini et al. (2010) \\
Cyphocharax plumbeus & Luque et al. (2011) \\
Gorytocephalus plecostomorum & Plecostomus plecostomum & Nickol and Thatcher (1971)
\end{tabular}

$(90.47 \%)$ than in the present study, but with higher infection intensity (52.63 versus 41.5$)$.

Thus far, metacercariae of $S$. musculosum have been found in a few fish species (CESCHINI et al., 2010; TAKEMOTO et al., 2009; ABDALLAH et al., 2005). In the present study, the Berger-Parker index showed that this digenean was the dominant species in S. insculpta, corroborating the findings of Zago et al. (2013) and suggesting that this fish species is highly susceptible to infections with this parasite. Moreover, this parasite species was found in the larval stage, suggesting that $S$. insculpta is in an intermediate position in the food chain and that it might be part of the diet of some piscivorous birds that are the definitive hosts of $S$. musculosum (ZAGO et al., 2013).

All the specimens of metacercariae of $S$. musculosum found in the present study were in the eyes of $S$. insculpta. A fish parasitized with approximately 40 metacercariae is likely to have cataracts or even blindness, depending on the size of the fish (EVANS et al., 1976 apud ZAGO et al., 2013). Thus, high infection rates by these metacercariae in the eyes reinforce this information, since the fish are weakened and become easy prey for the definitive host, thereby allowing this parasite to finish its life cycle (ABDALLAH et al., 2005; ZAGO et al., 2013).

Anacanthoroides mizelli and G. plecostomorum were also found at high prevalence, but low abundance (2.15 and 3.4, respectively). There is only one record of $A$. mizelli in freshwater fish, which was in Prochilodus reticulatus (KRITSKY; BOEGER, 2002), whose biology is similar to $S$. insculpta, since they are both iliophagous species (DUKE ENERGY, 2008). For G. plecostomorum, there is also only one record in fresh water fish, which was Plecostomus plecostomus (NICKOL; THATCHER, 1971). This fish is demersal (DUKE ENERGY, 2008) feeding on the substrate, like iliophagous species. Therefore, as shown in the present study, there is the possibility that $P$. reticulatus, $P$. plecostomus and $S$. insculpta may acquire the same parasite, since they might be ingesting the same intermediate hosts that dwell in the substrate, and also share the same habitat.

Vidal-Martínez et al. (2010) affirmed that bioindicators are species that reflect environmental impacts. In a review of parasites (helminths, crustaceans and protozoans) as potential indicators, these authors compiled pertinent data from 1997 to 2008 and grouped some environmental impact variables with parasites that showed significant interaction. These analyses demonstrated, through field and laboratory observations, that these interactions between parasites and eutrophication, pulp-mill effluents, crude oil, PCBs (polychlorinated biphenyls), pesticides or heavy metals can be positive, negative or null.

Monogeneans are fish ectoparasites with a direct life cycle that are found on the skin, in the nasal operculum and on the gills of the hosts (THATCHER, 2006). Thus, these parasites are in direct contact with the environment (NACHEV, 2010) and are very sensitive to any change in water parameters (BAYOUMY et al., 2008). Therefore, studies on monogeneans as biomarkers have been conducted by taking different approaches: Siddall et al. (1997) assessed the effects of exposure to relatively high concentrations of effluents from a pulp and paper mill on the prevalence, abundance and distribution of Dactylogyrus spp. on the gills of Rutilus rutilus that was sampled in Saravesi Lake, Finland. They found a significant discrepancy between ectoparasite levels and effluent concentration. Vital (2008) compared the parasitism indexes of the host Pygocentrus nattereri sampled in different phases of the hydrological cycle of Piranha Lake, Amazonas, Brazil, and pointed out that there was a significant difference in intensity of Dactylogyridae between the rainy and dry seasons. Bayoumy et al. (2008) studied monogeneans of some fish in the Gulf of Suez, Red Sea, as bioindicators for heavy metals, and found highly significant positive relationships between water temperature and prevalence of monogeneans, as well as between metal concentrations and prevalence. Madi and Ueta (2009) analyzed the role of monogeneans 
belonging to the Ancyrocephalinae family parasitizing Geophagus brasiliensis, as environmental bioindicators in reservoirs with distinct trophic characteristics in the state of São Paulo, Brazil (Juqueri reservoir - eutrophic; Jaguari reservoir - oligomesotrophic), and showed that variations in the prevalence and intensity of infection of these parasites were associated with variations in the amount of suspended material in the water of each reservoir.

It was observed in the present study that the prevalence and mean abundance of total monogeneans and $A$. mizelli were significantly greater in the lentic stretch. This significant difference corroborates previous studies that reported the use of monogeneans as indicators of environmental impact (SIDDALL et al., 1997; VITAL, 2008; BAYOUMY et al., 2008; MADI; UETA, 2009). Furthermore, this study evaluated the use of these parasites as environmental indicators for the effect of an impoundment (Jurumirim dam) on parasite communities, an approach that has not previously been reported in the literature.

Monogeneans are more easily found in lentic environments, since it is less difficult for their free-swimming larvae to reach the hosts (DOGEL, 1961). Therefore, this greater number of monogeneans may be due to the decreased water flow in the lentic environment, which enables more exchange of parasites among the hosts.

Steindachnerina insculpta is a fish species with iliophagous feeding habit that is important for food chain maintenance (REIS et al., 2003). Nevertheless, high monogenean infestations on the gills may threaten the breathing capacity of the fish, leading to death. Thus, a reduction in the number of these fish specimens may bring about impacts for other fish species that feed on S. insculpta, thus corroborating affirmations about the impacts of impoundments upon fish assemblages and parasite fauna (GABRIELLI; ORSI, 2000; AGOSTINHO et al., 2007).

This study contributes particularly towards initial characterization of the helminth fauna of $S$. insculpta in the Taquari River, in which nine taxa were found, thereby widening the knowledge of the geographical distribution of these parasites. Moreover, this study reports new records for $S$. inscultpa as a host for the monogeneans A. mizelli, D. kabatai and E. chaoi, and the acanthocephalan G. plecostomorum. Furthermore, this study indicates that the total monogenean and $A$. mizelli parasitism of $S$. insculpta could be used as potential bioindicators, due to their greater prevalence and abundance in the lentic gradient.

\section{Acknowledgements}

The authors thank FAPESP (2010/19543-6) and CAPES (AUX-PE-PNPD 3005/2010) for funding the project, and CAPES for the scholarship granted to the first author.

\section{References}

Abdallah VD, Azevedo RK, Luque JL. Metazoários parasitos dos lambaris Astyanax bimaculatus (Linnaeus, 1758), A.parahybae Eigenman, 1908 e Oligosarcus hepsetus (Cuvier, 1829) (Osteichthyes: Characidae), do Rio Guandu, Estado do Rio de Janeiro, Brasil. Rev Bras Parasitol Vet 2004; 13(2): 57-63.
Abdallah VD, Azevedo RK, Luque JL. Ecologia da comunidade de metazoários parasitos do sairú Cyphocharax gilbert (Quoy e Gaimard, 1824) (Characiformes: Curimatidae) do Rio Guandu, estado do Rio de Janeiro, Brasil. Rev Bras Parasitol Vet 2005; 14(4): 154-159. PMid:16445872.

Abdallah VD, Azevedo RK, Carvalho ED, Silva RJ. New hosts and distribution records for nematode parasites of freshwater fishes from São Paulo State, Brazil. Neotrop Helminthol 2012; 6(1): 43-57.

Agostinho AA, Gomes LC, Pelicice FM. Ecologia e Manejo de Recursos Pesqueiros em Reservatórios do Brasil. Maringá: Eduem; 2007.

Agostinho AA, Pelicice FM, Gomes LC. Dams and the fish fauna of the Neotropical region: impacts and management related to diversity and fisheries. Braz J Biol 2008; 68(4 Suppl): 1119-1132. PMid:19197482. http://dx.doi.org/10.1590/S1519-69842008000500019

Almeida KSS, Cohen SC. Diversidade de Monogenea (Platyhelminthes) Parasitos de Astyanax altiparanae do Reservatório da Usina Hidrelétrica de Itaipu. Saúde \& Amb Rev, Duque de Caxias 2011; 6(1): 31-41.

Bayoumy EM, Osman HAM, El-Bana LF, Hassanain MA. Monogenean Parasites as Bioindicators for Heavy Metals Status in Some Egyptian Red Sea Fishes. Global Vet 2008; 2(3): 117-122.

Begon M, Townsend CR, Harper JL. Ecologia de Individuos a Ecossistemas. 4th ed. Porto Alegre: Artmed; 2007.

Brandão H, Vidotto-Magnoni AP, Ramos IP, Carvalho ED. Assessment of the ichthyofauna in stretches under the influence of Salto Grande Reservoir (Middle Paranapanema River, SP/PR, Brazil). Acta Limnol Bras 2009; 21(4): 451-463.

Britto SGC, Carvalho ED. Ecological attributes of fish fauna in the Taquaruçu Reservoir, Paranapanema River (Upper Paraná, Brazil): composition and spatial distribution. Acta Limnol Bras 2006; 18(4): $377-$ 388.

Bush AO, Holmes JC. Intestinal helminths of lesser scaup ducks: an interactive community. Can J Zool 1986; 64(1): 142-152. http://dx.doi. org/10.1139/z86-023

Bush AO, Lafferty KD, Lotz JM, Shostak AW. Parasitology meets ecology on its own terms: Margolis et al. revisited. J Parasitol 1997; 83(4): 575-583. PMid:9267395. http://dx.doi.org/10.2307/3284227

Ceschini TL, Takemoto RM, Yamada FH, Moreira LHA, Pavanelli GC. Endoparasites of Steindachinerina brevipinna (Eigenmann and Eigenmann, 1889), collected in the tributaries Corvo and Guairacá of Paranapanema River, Paraná State, Brazil. Acta Sci Biol Sci 2010; 32(2):125-130. http://dx.doi.org/10.4025/actascibiolsci. v32i2.4102

Dogel VA. Ecology of the parasites of freshwater fishes. In: Dogel VA, Petrushevski GK, Polyanski YI. Parasitology offishes. Leningrad: University Press; 1961. p. 1-47.

Duke Energy. Peixes do rio Paranapanema. 2nd ed. Horizonte Geográfico: São Paulo; 2008.

Eiras JC, Takemoto RM, Pavanelli GC. Métodos de estudo e técnicas laboratoriais em parasitologia de peixes. 2nd ed. Maringá: Eduem; 2006.

Freeman MC, Bowen $\mathrm{ZH}$, Bovee KD, Irwin ER. Flow and habitat effects on juvenile fish abundance in natural and altered flow regimes. Ecol Appl 2001; 11(1): 179-190. http://dx.doi.org/10.1890/10510761(2001)011[0179:FAHEOJ]2.0.CO;2 
Gabrielli MA, Orsi ML. Dispersão de Lernea cyprinacea (Linnaeus) (Crustacea, Copepoda) na região norte do estado do Paraná, Brasil. Rev Bras Zool 2000; 17(2): 395-399. http://dx.doi.org/10.1590/S010181752000000200010

Henry R, Nogueira MG. A Represa de Jurumirim (São Paulo): Primeira síntese sobre o conhecimento limnológico e uma proposta preliminar de manejo ambiental. In: Henry R. Ecologia de reservatórios: estrutura, função e aspectos sociais. Botucatu: Fapesp/Fundibio; 1999. p. 651-685.

Junk WJ, Bayley PB, Sparks RE. The flood pulse concept in riverfloodplain systems. Can Spec Publ Fish Aquat Sci 1989; 106: 110-127.

Krebs CJ. Ecological methodology. New York: Harper \& Row; 1989.

Kritsky DC, Boeger WA. Neotropical Monogenoida. 41. New and previously described species of Dactylogyridae (Platyhelminthes) from the gills of marine and freshwater perciform fishes (Teleostei) with proposal of a new genus and a hypothesis on phylogeny. Zoosystema 2002; 24(1): 7-40.

Kritsky DC, Thatcher VE. New monogenetic trematodes from freshwater fishes of Western Colombia with the proposal of Anacanthoroides gen. n. (Dactylogyridae). Proc Helminthol Soc Wash 1976; 43(2): 129-134.

Luque JL, Aguiar JC, Vieira FM, Gibson DI, Santos CP. Checklist of Nematoda associated with the fishes of Brazil. Zootaxa 2011; 3082: 1-88.

Madi RR, Ueta MT. O papel de Ancyrocephalinae (Monogenea: Dactylogyridae), parasito de Geophagus brasiliensis (Pisces: Cichlidae), como indicador ambiental. Rev Bras Parasitol Vet 2009; 18(2): 38-41. http://dx.doi.org/10.4322/rbpv.01802008

Mendonza-Franco EF, Reina RG, Torchin ME. Dactylogyrids (Monogenoidea) parasitizing the gills of Astyanax spp. (Characidae) from Panama and Southeast Mexico, a new species of Diaphorocleidus and a proposal for Characithecium n. gen. J Parasitol 2009; 95(1): 46-55. PMid:19245277. http://dx.doi.org/10.1645/GE-1592.1

Nachev M. Bioindication capacity of fish parasites for the assessment of water quality in the Danube River [Thesis]. Germany: Universität DuisburgEssen; 2010.

Nickol BB, Thatcher VE. Two new acanthocephalans from Neotropical fishes: Neoechinorhynchus prochilodorum sp. n. and Gorytocephalus plecostomorum gen. et sp. n. J Parasitol 1971; 57(3): 576-581. PMid:5090966. http://dx.doi.org/10.2307/3277919

Overstreet RM. Parasitological data as monitors of environmental health. Parassitologia 1997; 39(3): 169-175. PMid:9802064.

Pavanelli, GC, Takemoto RM. Aspects of the ecology of proteocephalid cestodes, parasites of Sorubim lima (Pimelodidae), of the Upper Paraná River, Brazil: II. Interspecific associations and distribution of gastrintestinal parasites. Braz J Biol 2000; 60(4): 585-590. PMid:11241956.

Pereira C. Travnema travnema n. gen. n. sp. (Nematoda: Oxyuridae) parasito de Curimatus elegans (Pisces: Characinidae) no Nordeste Brasileiro. In: Livro Jubilar do Dr. Lauro Travassos. Rio de Janeiro; 1938. v. 3, p. 318-385.

Poulin R. The disparity between observed and uniform distributions - A new look at parasite aggregation. Int J Parasitol 1993; 23(7): 937-944. http://dx.doi.org/10.1016/0020-7519(93)90060-C

Reis RE, Kullander SO, Ferraris CJ. Check list of the freshwater fishes of South and Central America. Porto Alegre: EdiPUCRS; 2003.

Rózsa L, Reiczigel J, Majoros G. Quantifying parasites in samples of hosts. J Parasitol 2000; 86(2): 228-232. PMid:10780537.

Siddall R, Koskivaara M, Valtonen ET. Dactylogyrus (Monogenea) infections on the gills of roach (Rutilus rutilus L.) experimentally exposed to pulp and paper mill effluent. Parasitology 1997; 114(5): 439-446. http://dx.doi.org/10.1017/S003118209600875X

Sures B. Environmental parasitology: relevancy of parasites in monitoring environmental pollution. Trends Parasitol 2004; 20(4): 170-177. PMid:15099556. http://dx.doi.org/10.1016/j.pt.2004.01.014

Takemoto RM, Pavanelli GC, Lizama MAP, Lacerda ACF, Yamada FH, Moreira LHA, et al. Diversity of parasites of fish from the Upper Paraná River floodplain, Brazil. BrazJ Biol2009; 69(2 Suppl): 691-705. PMid:19738975. http://dx.doi.org/10.1590/S1519-69842009000300023

Thatcher VE. Aquatic Biodiversity in Latin America Biodiversidade Acuática en América Latina - Amazon Fish Parasites. 2nd ed. Moscow: Pensoft; 2006.

Vidal-Martínez VM, Pech D, Sures B, Purucker T, Poulin R. Can parasites really reveal environmental impact? Trends Parasitol 2010; 26(1): 44-51. PMid:19945346. http://dx.doi.org/10.1016/j.pt.2009.11.001

Vital JF. Diversidade de Parasitas de Pygocentrus nattereri (Kner, 1858) (Characiformes: Characidae) durante o ciclo hidrológico em um lago de várzea e seu potencial como indicadora de qualidade ambiental [Dissertação]. Manaus: Universidade Federal do Amazonas, Instituto Nacional de Pesquisas da Amazônia; 2008.

Zago AC, Franceschini L, Ramos IP, Zica EOP, Wunderlich AC, Carvalho ED, et al. Sphincterodiplostomum musculosum (Digenea, Diplostomidae) infecting Steindachnerina insculpta (Characiformes, Curimatidae) in the Chavantes Reservoir, Southeastern Brazil. Rev Bras Parasitol Vet 2013; 22(1): 98-103. PMid:24252954. http://dx.doi.org/10.1590/ S1984-29612013000100018 